\title{
Mobilising Land Value Increments for Urban Development: Learning from the Latin America Experience ${ }^{1}$
}

By

\author{
Martin O. Smolka and Fernanda Furtado
}

February 2002

\section{Introduction}

Increases in the value of urban land are often considered unearned or undeserved, in the sense that there is very little that landowner can do to increase the value of the land itself - as opposed to the buildings on it. Most increases in the value of specific pieces of urban land - relative to other pieces - result from direct or indirect public action: public infrastructure investments, or permission to develop the land in certain ways. Most general increases in urban land values reflect population growth and urbanisation, not the specific actions of urban landowners. It is sociably desirable to capture all or part of the increased value for the public sector. ${ }^{2}$ Over the past five years, the Lincoln Institute has supported the study of incremental land value capture policies and instruments in a number of Latin American countries (Smolka and Furtado, 2001). Notwithstanding the diversity of approaches and the variety of specific cases, we have identified a number substantive conclusions and lessons. These are presented in the third section, following some clarification of the concepts and issues

\section{Concepts and issues}

Value capture refers to the mobilisation of some or all of those land value increments that can be attributed to the community's efforts, so as to convert them into public revenues, either by fiscal measures (taxes, tariffs, contributions and other measures)

\footnotetext{
${ }^{1}$ The authors appreciate the editorial revision made by Mick Moore, and take full responsibility for posible remaining errors and omissions.

2 The argument that such a policy is ethical, efficient, equitable and sustainable is associated historically with Henry George (Brown and Smolka 1997).
} 
or, more directly, through the private beneficiary undertaking on-site improvements that benefit the inhabitants or the community in general. This definition does only not take into account value capture instruments in the narrow sense of the term: the taxation of land value increments (plusvalias in Spanish), as practised for example in Colombia, Mexico and Ecuador. The definition also includes situations where the participants or stakeholders in a project that generates land value increments benefit directly, for example, through taking a share in the land that has increased in value.

If public action can result in an increase in the relative price of a piece of land, it can also in some circumstances result in the opposite: the loss of value. This phenomenon is sometimes termed minusvalías in Latin America. ${ }^{3}$ Why do we not pay equal attention here to both plusvalias (windfalls) and minusvalias (wipeouts)? First, the latter is very much the exceptional case. Given population growth, urbanisation and the fixed supply of land, public interventions - in the form of provision of infrastructure and urban services or of land use regulation - tend generally to trigger large increases in urban land values. Second, public authorities seem less eager to capture plusvalias than to compensate for the minusvalias that result from their actions. The general rule in Latin America has been 'reverse value capture': generous compensation when expropriating properties for public projects (Maricato, 2000). ${ }^{4}$

In the political arena, arguments in favour of value capture are made by representatives of the left (progressives) as well as from the right (conservatives or neo-liberals). For those on the left, value capture makes it possible to control market excesses, such as land speculation, besides providing a way to extend land value taxation. The most radical expression of this idea is found in Cuba, where the state still holds, directly, or indirectly through its enterprises and public entities, a large stock of land, even within city limits and in privileged areas. Another example may be found among grassroots social movements in Brazil, which promote progressive

\footnotetext{
${ }^{3}$ The British term planning blight refers to the same general idea: the scheduling of an urban area as eligible for, for example, future major road development might severely depress the prices of surrounding residential properties.

${ }^{4}$ One can place in this category the discounts on property taxes offered in Rio de Janeiro in areas that border on favelas with problems of violence.
} 
property tax as an antidote to land speculation, notably by large landowners in urban peripheries, and as an alternative source of local revenues. Theorists from the right support value capture - above all in the form of charges applied at the margin - to promote market efficiency. It may inhibit free riders, and so achieve a closer fit between social costs/benefits to private owners. It can be a mechanism to enforce the principle of economic liberalism that each agent should be responsible for the cost it imposes on society - thereby limiting public expenditure on items that have not been assigned priority by the population. ${ }^{5}$

More pragmatic support for value capture policies comes from the urban planning discipline. Some practitioners find it a useful means of promoting urban developments that are socially inclusive and consistent with urban master plans. Such views are well represented in Colombia. Even critics of comprehensive urban planning also see value capture policies as an integral part of strategies to make urban developments more viable, or as a guarantee of the political sustainability of largescale individual projects. This view has shaped urban development strategies in São Paulo in particular. Value capture policies also find supporters in the public finance arena. Some support comes from those who believe that property taxes are in general excessive. Value capture is then seen as a specific means of funding new developments without burdening most property owners. ${ }^{5}$ Conversely, those who believe that urban property is insufficiently taxed see value capture as a useful step in the right direction, and a means to promoting a positive tax culture. There appears to

\footnotetext{
${ }^{5}$ This principle still guides public policy in Chile.

${ }^{5}$ There is a great deal of resistance to property taxes in both North and Latin America. That is one reason why value capture instruments - impact and development fees - are widely used in North America in particular. Some local authorities are have placed caps on the collection of property taxes, and in some cases these have become deeply entrenched. In 1993 the Santo André (Brazil) city administration passed a law granting a 40 percent reduction on the property tax, to be valid only for one year. However, this reduction has been maintained and become an effective tax cap because of pre-existing law stating that the value of the tax in the current year could not exceed its value in the previous year.
} 
be a mutually reinforcing relationship between public expenditures that increase the value of land, and revenues that are raised as a result of this increased value.

There is thus support for the idea of value capture from many quarters. There are also many disagreements about the mode of implementation, and a great deal of outright opposition, some of it fierce and ideological, based on defe nce of private property rights.

\section{Some conclusions from the Latin American experience ${ }^{6}$}

Notwithstanding the diversity of approaches to and experiences of land value capture in Latin America, it is possible to draw some broad conclusions.

\section{Value capture is not a new concept in Latin America.}

Public debates on the use of value capture and related instruments have been held since the beginning of the twentieth century in several Latin American countries. In the 1920s, the debate was triggered by specific events, such as the problem of paving streets in São Paulo, Brazil, and the lack of external financing for needed public works in Colombia. In other cases, political and ideological factors have motivated national discussions. Representatives of the Radical Party made several attempts to introduce the idea in Chile, and in the 1930s President Aguirre Cerda proposed legislation to create a national tax on land value increments based on the ideas of Henry George.

\section{However, its application in the urban policy agenda is still limited.}

Despite accumulated experiences of practical applications of the principles of value capture, the policy is not widely employed or even debated within the sphere of urban policy. In some instances, promising value capture initiatives have gained prominence in their own times, only to be forgotten later. An important example is the wellknown Lander Report from Venezuela, which proposed in the 1960s that land and its increments in value should be the main source of financing for urban development

\footnotetext{
${ }^{6}$ In this section we have used information from several studies conducted by the Lincoln Institute of Land Policy in the last five years.
} 
projects. That report formed the basis for recommendations on urban development finance included in the proceedings of the Habitat I international conference in 1976. Opportunities to use value capture as a tool for urban policy are being lost or ignored. Currently some Latin American countries are not taking advantage of potential unearned land value increments generated by major inner-city revitalisation projects. While there is widespread acceptance of the principle of capturing increases in land values that derive from public action, little in reality has been captured.

\section{Legislation often exists but is not implemented.}

As in many countries in the region, the variety of value capture instruments available in Mexico, ranging from the contribución por mejoras (a special assessment or betterment levy aimed at recovering the costs of public works) to taxes on plusvalías, illustrates the discrepancy between what is legally possible and what is actually implemented. Contrary to what is often alleged, the general problem is not that the planners or local officials lack understanding. The problems are rather that:

- The legislation and administrative procedures are often conceived and designed (sometimes intentionally) in such confusing and contradictory ways that they are almost impossible to employ in practice. For example, the Venezuelan national expropriation law of 1947 prescribes the taxation of 75 percent of land value increments related to public works, whereas the general municipal constitution (Ley Orgánica de Régimen Municipal) limits taxation to 5 percent of the total value of the affected property. In reality, even this limited charge is not collected.

- The law itself may be difficult to interpret. For example, the debate between eminent jurists in the 1970s in Brazil with respect to the constitutionality of the legislation on solo criado - an instrument based on the separation of land and building rights - reflected a basic lack of understanding of legal precedents regarding value capture and its associated instruments.

- The possibilities of the law are not always widely known, even within individual countries. In the Mexican city of Mexicali the traditional property tax, based on the combined value of land and buildings, was successfully replaced by a tax based exclusively on land value (Perlo and Zamorano 1999). Other cities in 
Mexico do not seem to be aware of or have not taken advantage of similar provisions in their state's legislation.

\section{There is strong ideological resistance}

This strong resistance to value capture may take the form of misleading interpretations, stereotyped objections or opposition on abstract principle. It is not hard to find arguments to justify the view that the application of value capture instruments is neither timely nor appropriate: for example, that taxes on land values are inflationary and disruptive of well-functioning markets, or that they involve unacceptable double taxation of the same asset. ${ }^{7}$ Stereotyped objections include:

- The revenues from value capture are not significant or are not justified when compared with the administrative costs incurred.

- The public administration would not have the technical competence or human resources effectively to implement value capture.

- The application of value capture instruments would be antisocial and regressive, since poor populations, which have the greatest need for more urban infrastructure, have the least capacity to pay. ${ }^{8}$

Finally, some objections are of a purely ideological nature. The resistance to the implementation of participación en plusvalias in Colombia, for example, is based on the allegation that this device, although recognised as technically well-formulated, represents one more unwanted public 'interference' in the urban real estate business, on the same lines as higher taxation, limitations on property rights or increased regulation (Barco de Botero and Smolka 2000).

\section{$\underline{\text { 5. Value capture is gradually becoming more popular. }}$}

${ }^{7}$ Such arguments seem to lie behind the reluctance of the Ministry of Housing and Urbanism of Chile to promote the review and resubmission to the Congress of some value capture provisions in the country's new legal framework on urban development.

${ }^{8}$ There is however contrary experience, notably from Chile, Brazil and Peru, of successful participatory development programmes among poor urban populations that were financed by value capture. 
Despite of the obstacles and political resistance, recent Latin American experience with value capture shows a growing interest in the subject. Value capture is attracting the attention of municipal planners throughout the region, and it is beginning to be perceived as an important urban policy initiative. This growing popularity results from several factors. First, greater administrative and fiscal decentralisation gives urban administrations more fiscal autonomy and responsibility, and so encourages them to look for new revenue sources. The need for more local resources has been reinforced by the social demands and political pressures for public spending associated with current democratisation processes and growing levels of popular participation. Almost all new value capture initiatives are associated with, and motivated by, the creation of extra-budget funds to finance special social programmes. Second, the redefinition of the functions of the state, including privatisation, together with the decline of comprehensive planning, have set the stage for the development of more flexible public interventions, public-private partnerships, and direct negotiations in land use and land use regulation. The release of public land into the private land market, as well as better coordination between real estate and public sector interests to promote new areas in the cities, are also significant. ${ }^{9}$ Other favourable factors include support from international financial institutions for levying user charges on public facilities and the recovering of the costs of public investments from beneficiaries. The growing popularity of new value capture instruments can also be attributed to some frustration with the poor results obtained from the application of taxes and other traditional charges related to urban land in past decades, in terms of both revenues and urban policy objectives.

\section{Pragmatism overrides ethical or theoretical justifications.}

A corollary to the preceding point is that the growing popularity of value capture seems to be inspired more by pragmatism than by ethics, notions of equality, or theoretical and political justifications. Some reforms may even have been introduced without full political awareness of the process, or of its theoretical importance, as

\footnotetext{
${ }^{9}$ It is worth noting that even in Cuba one finds a vigorous program through which the Office of the Historian in Havana, operating as a kind of property holding company, refinances its state-owned operations with land value increments resulting from urban renovation projects in the form of rents charged to private development partners.
} 
previously illustrated in the Mexicali case. The historical evidence shows that most value capture initiatives have responded above all to the need to face fiscal crises and other local problems in the financing of urban development. This is the case even in Argentina, where the need for revenues prevailed over established principles of opposition to new taxes. A temporary five-percent increase in the property tax was used as one of the initiatives to finance investments in the new Buenos Aires subway system.

\section{Experience with implementing value capture is useful in refining the system}

This is illustrated by the Colombian experience with the contribución de valorización since the 1920s and the many attempts to overcome some of its limitations, especially in the past 40 years. The recently enacted law on participación en plusvalias is a more technically developed and politically acceptable version of an instrument targeted to capture the sometimes huge land value increments associated with administrative decisions concerning zoning, density levels and other urban planning regulations.

\section{$\underline{\text { 8. Value capture is not necessarily progressive or redistributive. }}$}

As we noted above, support for value capture is in no way a monopoly of the political left. It has recently been implemented in neo-liberal contexts in Argentina and Chile. The São Paulo version, known as operacões interligadas (linkage operations) has been employed by city administration from opposing political and ideological tendencies. Equally, progressive local governments are sometimes reluctant to apply these instruments, and may even reject them notion altogether, for three reasons. First, they may believe that such contributions would be simply a mechanism to impose additional fiscal charges with no redistributive impact whatsoever. Second, even when the resulting revenues are earmarked for the low-income population, they may be insufficient to reduce the absolute differences between rich and poor in the access to serviced land (Furtado, 1999). Third, they may heed the intergenerational argument that value capture charges are being imposed on newer, generally poor, residents who need services, whereas earlier generations were not charged for infrastructure services or amenities. The "Robin Hood" image of value capture policies fades once it becomes clear that often only a very small part of the increased value that the owner receives is actually captured for public purposes. This point seems to have been well understood by many lower-income populations, like those in 
Lima, where a successful programme featuring some 30 projects used the contribución de mejoras to finance public works in the early 1990s. The alleged inability of poor urban populations to pay for improved services appears often to be a myth. In practice, the strategy of attracting some public intervention to one's neighbourhood - even if it means paying some of the costs - may be better for poor people than the alternative: neglect. This point should, nevertheless, be taken with caution, in light of certain experiences where the value capture has been applied in low-income areas with purposes other than benefiting the occupants - for example, to justify the eviction or force the departure of those who cannot pay for the improvements.

\section{Final Considerations}

Despite the unimpressive history outlined above of attempts to introduce or implement value capture in Latin America, value capture policies are undeniably arousing new interest and becoming more acceptable. Initiatives to implement the principle have grown in both number and creativity, and its virtues - beyond being simply an alternative source of public revenue - are becoming better understood. Public authorities are realising that their prerogatives to control land use rights and to determine the location and timing of pub lic works can be bargained for contributions to the public good from the beneficiaries of those decisions. They also see that transparent discussions over these issues reduces the scope for "under the table" deals. As the link between public intervention and land value increase is becoming more visible, attitudes are changing to be more conducive to building a fiscal culture that will strengthen property taxes and local revenues in general. Much remains to be done in two spheres: researching the complex nature of value capture policies; and promoting greater understanding among public officials with regard to how it can be used to benefit their communities. 


\section{References}

Barco de Botero, C. and Smolka, M. O. (2000) Challenges in Implementing Colombia's Participación en Plusvalías in Landlines Newsletter of the Lincoln Institute of Land Policy May Volume 12 N.3

Brown, H. J. and Smolka, M.O. 1997 “Capturing Public Value from Public Investments" in Brown, H. James (Ed.) Land Use \& Taxation: Applying the Insights of Henry George, Lincoln Institute of Land Policy, Cambridge Massachusetts.

Furtado, Fernanda , (1999) Recuperação de mais-valias fundiárias urbanas na América Latina: debilidade na implementação, ambigüidades na interpretação. Tesis de Doctorado, Facultad de Arquitectura y Urbanismo de la Universidad de São Paulo.

Maricato, Erminia et. al. (2000), Preço de desapropriação de terras: Limites às políticas públicas nas áreas de habitação, meio-ambiente e vias públicas em São Paulo. LABHAB/FAUUSP y Lincoln Institute of Land Policy.

Perlo, M. and Zamorano, L.R. (1999) "La reforma al sistema fiscal sobre la propiedad inmobliaria en Mexicali: 1989-1998”. Lincoln Institute of Land Policy Working Paper, 1999.

Smolka , Martim and Furtado, Fernanda (2001) Recuperacion de Plusvalias en America Latina: Alternativas para el Desarrollo Urbano, Eurelibros, Chile, April 2001. 